\title{
Penentuan Faktor-Faktor yang Mempengaruhi Tingkat Fertilitas Di Indonesia Tahun 2017 Dengan Metode Multiple Classification Analysis (Analisis Data SDKI 2017)
}

\author{
Vivy Maharani ${ }^{1}$, Annisa Putri Ramadhanty ${ }^{2}$, Galang Madya Putra ${ }^{3}$, \\ Iqbal Mukti Pratama ${ }^{4}$, Risni Julaeni Yuhan ${ }^{5}$ \\ 1,2,3,4,5 Program Studi Diploma IV, Jurusan Statistika Sosial dan Kependudukan, \\ Politeknik Statistika STIS, \\ Jakarta 11480, Indonesia \\ 211710045@stis.ac.id;211709565@stis.ac.id;211709710@stis.ac.id; \\ 211709756@stis.ac.id; risnij@stis.ac.id
}

\begin{abstract}
Fertility is the ability to produce offspring associated with female fertility. The desired condition is for the population to grow in balance as a prerequisite for achieving a population without growth, where fertility, mortality rates are declining, and distribution is more evenly distributed. To achieve a Balanced Growing Population Condition (PTS), a total fertility rate (TFR) of 2.1 per woman is expected in 2015. However, based on the results of the 2017 Indonesia Health Demographic Survey (IHDS) fertility rate in Indonesia is 2.4. This has not met the desired conditions to achieve the Balanced Growing Population (PTS) condition. For this problem, it is necessary to do further research to find out the factors that affect the level of fertility or the number of children born to women. Researchers used the Multiple Classification Analysis (MCA) method to meet the aim of this study to determine the factors that influence the number of births. The results and discussion show that a mother who knows her ovulation cycle and / or lives in a city has an average number of children who are smaller than a mother who does not know her ovulation cycle and / or resides in the village. This happens because a mother who knows her ovulation cycle is more able to control the incidence of pregnancy compared to a mother who does not know her ovulation cycle.
\end{abstract}

Keywords - Multiple Classification Analysis (MCA); Fertility; Total Fertility Rate (TFR); Balance of Population Growth.

\begin{abstract}
ABSTRAK
Fertilitas adalah kemampuan menghasilkan keturunan yang dikaitkan dengan kesuburan wanita. Kondisi yang diinginkan adalah penduduk tumbuh seimbang sebagai prasyarat tercapainya penduduk tanpa pertumbuhan, dimana tingkat fertilitas, mortalitas semakin menurun, dan persebaran lebih merata. Untuk mencapai Kondisi Penduduk Tumbuh Seimbang (PTS), diharapkan angka kelahiran total/total fertility rate (TFR) 2,1 per wanita pada tahun 2015. Namun, berdasarkan hasil Survei Demografi dan Kesehatan Indonesia (SDKI) tahun 2017 tingkat fertilitas di Indonesia sebesar 2,4. Hal ini belum memenuhi kondisi yang diinginkan untuk mencapai kondisi Penduduk Tumbuh Seimbang (PTS). Atas permasalahan tersebut, maka perlu dilakukan penelitian lebih lanjut untuk mengetahui faktor-faktor yang mempengaruhi tingkat fertilitas atau jumlah anak yang dilahirkan wanita. Peneliti menggunakan metode Multiple Classification Analysis (MCA) untuk memenuhi tujuan penelitian mengetahui faktor-faktor yang berpengaruh terhadap jumlah kelahiran. Hasil dan pembahasan menunjukkan bahwa seorang ibu yang mengetahui siklus ovulasinya dan/atau bertempat tinggal di kota memiliki rata-rata jumlah anak yang lebih sedikit dibanding dengan ibu yang tidak mengetahui siklus ovulasinya dan/atau bertempat tinggal di desa. Hal ini terjadi karena seorang ibu yang mengetahui siklus ovulasinya, lebih dapat mengontrol kejadian kehamilan dibanding dengan ibu yang tidak mengetahui siklus ovulasinya.
\end{abstract}

Kata Kunci - Multiple Classification Analysis (MCA); Fertilitas, Total Fertility Rate (TFR); Penduduk Tumbuh Seimbang 


\section{PENDAHULUAN}

Saat ini Badan Pusat Statistik (BPS) sedang menyelenggarakan proyek besar sepuluh tahunan yang berkenaan dengan pencatatan penduduk, yaitu Sensus Penduduk. Terakhir, BPS mencatat jumlah penduduk Indonesia pada tahun 2015 adalah sebanyak 255,18 juta jiwa dan diproyeksikan bahwa jumlah penduduk Indonesia akan mencapai 269,6 juta jiwa pada tahun 2020 (Badan Pusat Statistik, 2016).

Salah satu komponen yang mempengaruhi pertumbuhan penduduk adalah fertilitas yang berkontribusi positif terhadap pertumbuhannya. Fertilitas adalah kemampuan menghasilkan keturunan yang dikaitkan dengan kesuburan wanita (BPS). Kondisi yang diinginkan adalah penduduk tumbuh seimbang sebagai prasyarat tercapainya penduduk tanpa pertumbuhan, dimana tingkat fertilitas dan mortalitas semakin menurun, sedangkan persebaran penduduk lebih merata. Untuk mencapai Kondisi Penduduk Tumbuh Seimbang (PTS), diharapkan angka kelahiran total (TFR) 2,1 per wanita pada tahun 2015. Kesejahteraan keluarga dan masyarakat akan lebih mudah dicapai apabila anak pada keluarga inti jumlahnya ideal, yaitu dua anak (WHO, 2004).

Menurut (WHO, 2004), fertilitas atau disebut juga dengan kelahiran hidup (live birth) adalah peristiwa keluarnya atau terpisahnya suatu hasil konsepsi berupa bayi dari rahim ibunya, tanpa memperdulikan lama kehamilan, kemudian bayi yang dilahirkan menunjukan adanya tanda-tanda kehidupan, diantaranya yaitu adanya detak jantung bayi, bergerak, bernafas, menangis dan sebagainya.

Dalam melihat tingkat fertilitas suatu negara salah satunya dengan melihat indikator yaitu jumlah anak yang dilahirkan hidup. Menurut Badan Pusat Statistik (BPS), anak lahir hidup memiliki definisi yaitu semua anak yang waktu lahir memeperlihatkan tanda-tanda kehidupan, walaupun sesaat, seperti adanya detak jantung, bernafas, menangis dan tanda-tanda kehidupan lainnya.

Salah satu faktor yang mempengaruhi tingkat fertilitas yaitu pengetahuan ibu terhadap siklus ovulasi. Siklus ovulasi adalah sebuah proses yang terjadi dalam siklus menstruasi seorang wanita. Ovulasi terjadi ketika pecahnya folikel telur yang matang dan melepaskan sel telur melalui tuba falopi ke arah rahim untuk mendapatkan pembuahan (ovulasi). Ovulasi terjadi secara teratur setiap bulannya yang berbanding lurus dengan siklus menstruasi yang teratur juga. Sehingga jika seorang wanita memiliki pengetahuan tentang siklus ovulasinya atau dengan kata lain mereka dapat mengidentifikasi siklus menstruasinya dan menentukan kapan puncak masa suburnya, maka mereka dapat menggunakan informasi untuk segera mendapatkan anak atau justru sebaliknya (Halodoc, 2020).

Selain itu, faktor yang juga mempengaruhi fertilitas adalah faktor demografi yaitu wilayah tempat tinggal. Sebagaimana disampaikan oleh Oey11 Hendershot (Nasrullah, 2013) bahwa perbedaan fertilitas antara migran rural-urban dan penduduk asli, dijelaskan melalui Teori Sosial Umum (General Social Theories), yang terdiri tiga teori. Pertama, Social Disorganization Theory yang menyatakan bahwa fertilitas migran jauh lebih tinggi daripada penduduk perkotaan dan bahkan lebih tinggi daripada fertilitas penduduk nonmigran di daerah asal. Kedua, Assimilation Theory, yang menyatakan bahwa fertilitas migran adalah rata-rata fertilitas antara penduduk perdesaan (nonmigran) dan penduduk pribumi perkotaan. Ketiga, Social Mobility Theory, yang mengatakan bahwa fertilitas migran lebih rendah, bahkan lebih rendah daripada penduduk pribumi perkotaan. Belum lagi adanya perbedaan pemikiran yang berkembang di masyarakat perkotaan dan perdesaan, diantaranya masyarakat perdesaan masih menganggap bahwa semakin banyak anak semakin banyak rejeki.

Menurut (Sugiarto, 2018), melakukan penelitian yang berjudul Multiple Classification Analysis (MCA) sebagai Metode Alternatif Analisis Data Untuk Variabel Bebas yang Kategori. Penelitian ini bertujuan untuk memberikan ilustrasi penggunaan metode MCA sebagai alternatif analisis data untuk data variabel bebas yang kategori, yaitu pada contoh penelitian mengenai pengaruh jenis pendidikan menengah atas, jenis kelamin, sektor pekerjaan, dan keikutsertaan pelatihan kerja terhadap lamanya waktu untuk mencari kerja. Hasil penelitian membuktikan bahwa penggunaan metode MCA lebih mudah diterapkan dimana output dan koefisien yang dihasilkan lebih mudah dipahami dan hasilnya tidak berbeda jauh dengan metode yang dihasilkan dari RLB.

Selanjutnya (Hermanto, et al, 2016), melakukan penelitian yang berjudul Analisis Determinan Pendapatan Pekerja Miskin di Provinsi Aceh Tahun 2015. Penelitian ini bertujuan untuk menentukan model MCA pada faktorfaktor yang berpengaruh terhadap garis kemiskinan provinsi (GKP). Hasil MCA menunjukkan bahwa variabel bebas secara simultan memberikan pengaruh yang nyata terhadap pendapatan. Dari 8 variabel demografi yang diteliti, variabel bebas lapangan usaha, jenis kelamin, umur dan tingkat pendidikan mempunyai pengaruh yang besar terhadap pendapatan pekerja miskin. 
Dalam penelitian sebelumnya (Firdaus, et al, 2019), melakukan penelitian yang berjudul Penentuan Garis Kemiskinan Provinsi Menggunakan Metode Multiple Classification Analysis. Penelitian ini bertujuan untuk untuk menentukan model MCA pada faktor-faktor yang berpengaruh terhadap garis kemiskinan provinsi (GKP). Hasil analisis menunjukkan bahwa model MCA yang diperoleh juga memberikan hasil yang sangat baik karena memiliki nilai MAPE 8,93\%. Selain itu, menunjukkan bahwa variabel RLS, PDRB dan PPP berpengaruh signifikan terhadap GKP. PPP merupakan faktor yang paling berpengaruh terhadap GKP yaitu dengan nilai eta sebesar $71,9 \%$ dan beta sebesar 58,1\%. Sedangkan variabel PDRB memiliki nilai eta sebesar $65,7 \%$ dan nilai beta $39,9 \%$. Variabel RLS hanya memiliki nilai eta $47,2 \%$ dan beta sebesar $14,0 \%$.

Melalui program Keluarga Berencana pemerintah melakukan berbagai tindakan seperti penyuluhan dan pembentukan kader di masyarakat. Berdasarkan hasil Survei Demografi dan Kesehatan Indonesia (SDKI), penggunaan alat kontrasepsi di Indonesia mencapai 63,6 persen pada tahun 2017. Seiring dengan berkembanganya ilmu pengetahuan, sebuah keluarga akan mempertimbangkan jumlah anak dalam keluarga inti. Semakin banyak jumlah anak tentunya semakin banyak biaya yang dibutuhkan untuk kehidupan sehari-hari.

Namun, berdasarkan hasil SDKI tahun 2017 tingkat fertilitas di Indonesia sebesar 2,4. Hal ini belum memenuhi kondisi yang diinginkan untuk mencapai kondisi Penduduk Tumbuh Seimbang(PTS). Atas permasalahan tersebut, maka perlu dilakukan penelitian lebih lanjut untuk mengetahui faktor-faktor yang mempengaruhi tingkat fertilitas atau jumlah anak yang dilahirkan wanita. Penelitian ini bertujuan untuk mengetahui faktor-faktor yang berpengaruh terhadap jumlah kelahiran. Multiple Classification Analisys (MCA) cocok digunakan untuk data dengan variabel bebas kategorik. Selain itu, metode MCA lebih mudah diterapkan dimana output dan koefisien yang dihasilkan lebih mudah dipahami dan hasilnya tidak berbeda jauh dengan metode yang dihasilkan dari RLB. Hasil penelitian ini dapat memberikan rekomendasi kepada pemerintah untuk memahami dan mengatasi masalah kependudukan.

\section{METODOLOGI PENELITIAN}

\section{Metode Pengumpulan Data}

Penelitian ini menggunakan data sekunder yang berasal dari data Survei Demografi dan Kesehatan Indonesia (SDKI) Tahun 2017. Adapun responden dari data SDKI ini merupakan wanita dengan usia 15-49 tahun di seluruh Provinsi Indonesia. Jumlah responden wanita masing-masing provinsi hrus mewakili ukuran total sampel sesuai proporsi masing-masing provinsi. Pengumpulan data dilaksanakan dengan cara wawancara tatap muka (Badan Pusat Statistik, 2018). Adapun variabel variabel yang digunakan dalam penelitian ini dijabarkan pada tabel berikut.

Tabel 1 Variabel dan Kategorinya

\begin{tabular}{|c|c|c|}
\hline & $\begin{array}{l}\text { Variabel } \\
\text { (1) }\end{array}$ & $\begin{array}{l}\text { Kategori } \\
\text { (2) }\end{array}$ \\
\hline $\mathrm{Y}$ & $\begin{array}{l}\text { Jumlah Anak yang } \\
\text { Dilahirkan Hidup }\end{array}$ & Menggunakan skala rasio \\
\hline $\mathrm{X}_{1}$ & $\begin{array}{l}\text { Pengetahuan ibu } \\
\text { terhadap siklus ovulasi }\end{array}$ & $\begin{array}{l}1: \text { Tahu } \\
2: \text { Tidak tahu }\end{array}$ \\
\hline $\mathrm{X}_{2}$ & Wilayah tempat tinggal & $\begin{array}{l}1: \text { Perkotaan } \\
2: \text { Perdesaan }\end{array}$ \\
\hline
\end{tabular}

\section{Metode Analisis}

Metode analisis dalam penelitian ini menggunakan metode analisis deskriptif dan analisis inferensia. Analisis deskriptif dalam penelitian ini untuk mengetahui sebaran data dari variabel tak bebas. Sedangkan analisis inferensia menggunakan metode Multiple Classification Analisys (MCA). Seluruh pengolahan data dilakukan menggunakan software SPSS versi 24.

MCA merupakan sebuah teknik untuk menduga hubungan antara beberapa variabel bebas dan satu variabel tidak bebas serta menentukan efek dari masing-masing variabel bebas sebelum dan sesudah disesuaikan dengan variabel bebas lainnya. MCA didesain untuk variabel bebas yang diukur dalam skala kategorik, sedangkan variabel tidak bebasnya dalam skala rasio/interval. 
Langkah-langkah dalam analisis inferensia dengan metode MCA adalah sebagai berikut:

1. Menguji pengaruh variabel bebas baik secara simultan maupun parsial. Kedua uji ini dilakukan untuk mengetahui apakah ada pengaruh variabel pengetahuan ibu terhadap siklus ovulasi dan wilayah tempat tinggal terhadap variabel jumlah anak yang dilahirkan hidup. Pengujian ini dilakukan dengan menguji nilai F main effect. Hipotesis yang digunakan adalah sebagai berikut:

$\mathrm{H}_{0}$ : Tidak terdapat pengaruh variabe bebas terhadap variabel terikat

$\mathrm{H}_{1}$ : Minimal terdapat satu variabel bebas yang mempengaruhi variabel terikat

Statistik uji yang digunakan adalah sebagai berikut :

$$
\begin{gathered}
F=\frac{E /(C-P)}{(T-E) /(N+P-C-1)} \\
F_{a}=\frac{U_{a} /\left(C_{a}-1\right)}{\left(T-U_{a} /\left(N-C_{a}\right)\right.}
\end{gathered}
$$

Keterangan :

$\mathrm{F} \quad=$ nilai $\mathrm{F}$ secara simultan

$\mathrm{Fa} \quad=$ nilai $\mathrm{F}$ secara parsial variabel ke-a

$\mathrm{C}=$ jumlah seluruh kategori

$\mathrm{P} \quad=$ jumlah variabel independen

$\mathrm{T}=$ total sum of squares

$\mathrm{E} \quad=$ explained sum squares kuadrat

$\mathrm{C}_{\mathrm{a}}=$ jumlah kategori variabel ke-a

$\mathrm{U}_{\mathrm{a}}=$ jumlah kuadrat antar kategori

variabel ke-a

Keputusan : tolak $\mathrm{H}_{0}$ jika p-value $<\alpha$ (tingkat signifikansi) atau $\mathrm{F}_{\text {hitung }}>\mathrm{F}_{0,05(\mathrm{~V} 1, \mathrm{~V} 2)}$

2. Menguji ada tidaknya interaksi antar variabel bebas, yaitu menggunakan uji sigifikansi F pola interaksi antar variabel bebas yang terbentuk. Hipotesis yang digunakan yaitu :

$\mathrm{H}_{0}$ : Tidak terdapat interaksi antar variabel bebas

$\mathrm{H}_{1}$ : Terdapat interaksi antar variabel bebas

Statistik uji yang digunakan yaitu :

$F=$ Mean Square interaksi antar variabel bebas/Mean Square of Residual

Keputusan : tolak $\mathrm{H}_{0}$ jika p-value $<\alpha$ (tingkat signifikansi) atau $\mathrm{F}_{\text {hitung }}>\mathrm{F}_{0,05(\mathrm{~V} 1, \mathrm{~V} 2)}$

Apabila terdapat interaksi maka dilakukan penggabungan variabel sehingga terbentuk variabel baru

3. Menginterpretasikan output MCA

4. Menginterpretasikan besar pengaruh variabel bebas, yaitu dengan melihat dari nilai koefisien determinasinya

$\left(\mathrm{R}^{2}\right)$. Koefisien determinasi diperoleh dari:

$R^{2}=E / T$

$R_{a d j}^{2}=1-\left(1-R^{2}\right) A$

Keterangan :

$\mathrm{A}=$ derajat bebas adjusted

dimana,

$$
A=\frac{N-1}{N+P-C-1}
$$




\section{HASIL DAN PEMBAHASAN}

\section{Analisis Deskriptif}

Tabel 2 menyajikan hasil analisis deskriptif dari data yang ada. Berdasarkan hasil pengolahan, diketahui bahwa rata-rata jumlah anak yang dilahirkan hidup oleh wanita usia 15-49 tahun di Indonesia adalah 3 sampai 4 anak.

Tabel 2 Analisis Deskriptif

\begin{tabular}{|c|c|c|c|c|c|}
\hline & $\mathrm{N}$ & Minimum & Maximum & Mean & $\begin{array}{c}\text { Std. } \\
\text { Deviation }\end{array}$ \\
\hline & (1) & $(2)$ & (3) & (4) & $(5)$ \\
\hline Jumlah Anak yang Dilahirkan Hidup & 86265 & 1 & 13 & 3,38 & 1,842 \\
\hline $\begin{array}{l}\text { Pengetahuan ibu terhadap siklus } \\
\text { ovulasi }\end{array}$ & 86265 & 1,00 & 2,00 & 1,2045 & 0,40334 \\
\hline Wilayah tempat tinggal & 86265 & 1,00 & 2,00 & 1,52 & 0,5 \\
\hline
\end{tabular}

\section{Analisis Inferensia}

Selanjutnya akan dilakukan analisis inferensia untuk mengetahui faktor yang mempengaruhi jumlah anak lahir hidup menggunakan MCA. Adapun dalam melakukan analisis MCA, sebaran data perlu diketahui terlebih dahulu untuk melanjutkan ke uji pengaruh variabel.

\section{Sebaran Data Total Children Ever Born}

Hasil pengolahan data menunjukkan bahwa sebaran data jumlah anak yang dilahirkan hidup sebagai variabel dependent memiliki kecenderungan menceng kanan dengan nilai keruncingan (skewness) sebesar 1,307.

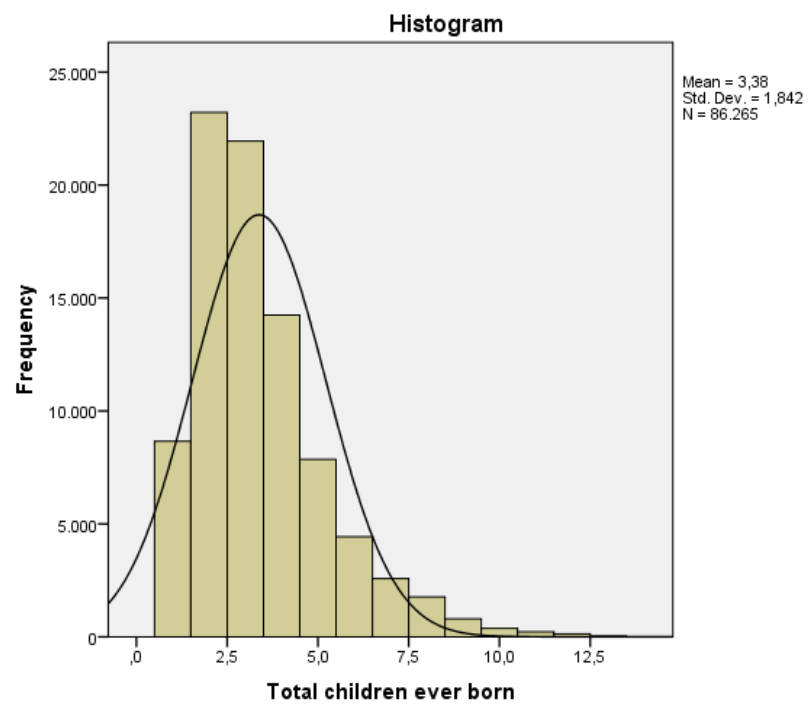

Gambar 1. Grafik Histogram Sebaran Total Children Ever Born

Sebaran data tidak boleh memiliki kemencengan yang ekstrim agar dapat dilanjutkan analisis MCA. Oleh sebab itu, perlu dilakukan transformasi data dengan logaritma natural (ln) untuk mengatasi permasalahan tersebut. Setelah peneliti melakukan transformasi data, diperoleh sebaran data jumlah anak yang dilahirkan hidup menjadi sebagai berikut. 


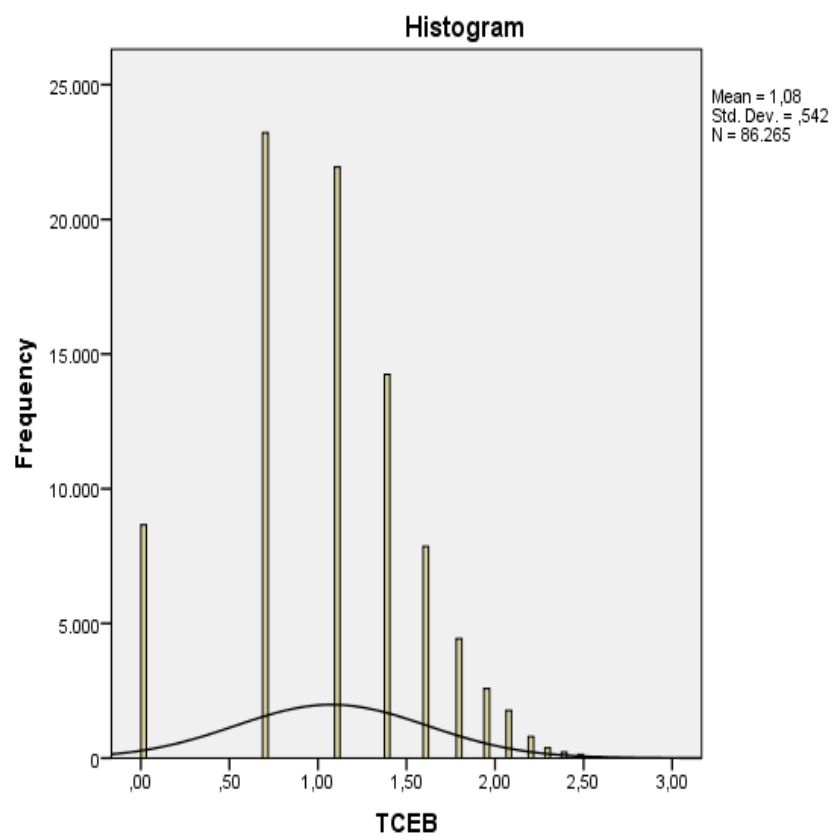

Gambar 2. Grafik Histogram Sebaran Total Children Ever Born (Data Transformasi)

\section{Uji Pengaruh Variabel}

Setelah kemencengan data dapat teratasi, data dapat dilanjutkan uji pengaruh variabel baik secara parsial maupun simultan.

\section{- Pengaruh Simultan}

Tahap selanjutnya dalam melakukan MCA adalah menguji pengaruh variabel bebas, dalam penelitian ini pengetahuan ibu terhadap siklus ovulasi dan wilayah tempat tinggal, secara simultan terhadap variabel tak bebas, yaitu jumlah anak yang dilahirkan hidup.

Tabel 3 Output Hasil ANOVA

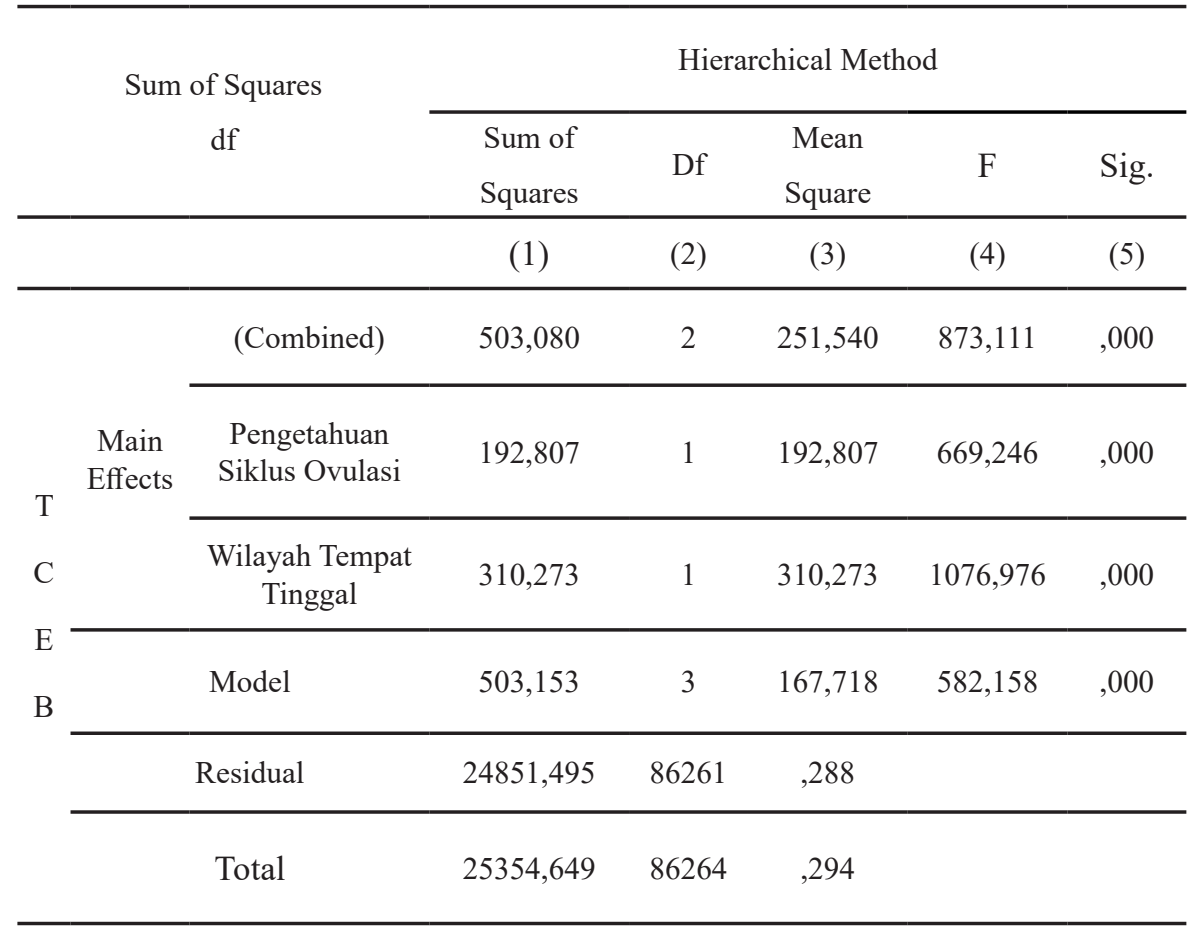

Hasil perhitungan dalam tabel anova menunjukkan bahwa p-value model menunjukkan nilai 0,000 (kurang dari alpha 0,05 ). Hal ini berarti variabel bebas secara bersama-sama signifikan mempengaruhi variabel tak bebas atau terdapat minimal satu variabel bebas yang memengaruhi variabel tak bebas. 


\section{- Pengaruh Parsial}

Uji pengaruh simultan sebelumnya menghasilkan informasi bahwa terdapat minimal satu variabel bebas yang mempengaruhi variabel tak bebas. Sehingga pengujian perlu dilanjutkan ke uji parsial untuk mengetahui variabel apa saja yang mempengaruhi jumlah anak yang dilahirkan. Hasil uji pengaruh variabel secara parsial diperoleh dari tabel anova yang sama. P-value kedua variabel menunjukkan nilai kurang dari alpha. Hal ini berarti variabel pengetahuan ibu terhadap siklus ovulasi dan wilayah tempat tinggal secara parsial signifikan mempengaruhi jumlah anak yang dilahirkan.

\section{Uji Interaksi}

Tahap selanjutnya dalam melakukan pengujian asumsi MCA adalah menguji apakah terdapat interaksi antar variabel bebas. Tabel interaksi ini diperoleh dari tabel anova sebelumnya.

Tabel 4 Uji Asumsi MCA

\begin{tabular}{lccc}
\hline & Nilai F & Sig. & Keputusan \\
\hline \multicolumn{1}{c}{$(1)$} & $(2)$ & $(3)$ & $(4)$ \\
\hline $\begin{array}{l}\text { Pengetahuan Siklus } \\
\begin{array}{l}\text { Ovulasi * Wilayah } \\
\text { Tempat Tinggal }\end{array}\end{array}$ & 252 &, 616 & Gagal Tolak H0 \\
\hline
\end{tabular}

Diperoleh hasil bahwa tidak ada interaksi yang signifikan antar variabel bebas. Demikian, pengujian asumsi dapat dicukupkan sampai disini untuk kemudian dapat dilanjutkan MCA.

\section{Hasil MCA}

Pola model hubungan variabel bebas dengan variabel tak bebas dalam MCA dapat dilihat dengan cara menambahkan grand mean (rata-rata total) dengan koefisien MCA dari masing-masing variabel. Nilai koefisien MCA ditunjukkan dengan nilai deviasi yang telah disesuaikan (Deviation Adjusted for Factors). Tanda negative koefisien MCA pada suatu kategori menunjukkan bahwa seorang ibu pada kategori tersebut memiliki jumlah anak yang dilahirkan lebih sedikit dibandingkan dengan kategori lain.

Tabel 5 Output Hasil MCA

\begin{tabular}{|c|c|c|c|c|c|c|c|}
\hline & & & \multirow[b]{2}{*}{$\mathrm{N}$} & \multicolumn{2}{|c|}{ Predicted Mean } & \multicolumn{2}{|c|}{ Deviation } \\
\hline & & & & Unadjusted & $\begin{array}{l}\text { Adjusted } \\
\text { for } \\
\text { Factors }\end{array}$ & Unadjusted & $\begin{array}{l}\text { Adjusted } \\
\text { for Factors }\end{array}$ \\
\hline & \multirow{2}{*}{$\begin{array}{c}\text { Pengetahuan } \\
\text { Siklus } \\
\text { Ovulasi }\end{array}$} & Tahu & 68624 & 1,0520 & 1,0557 &,- 02397 &,- 02019 \\
\hline $\mathrm{C}$ & & $\begin{array}{l}\text { Tidak } \\
\text { Tahu }\end{array}$ & 17641 & 1,1692 & 1,1545 & ,09324 & ,07853 \\
\hline \multirow[t]{2}{*}{ B } & Wilayah & Urban & 41327 & 1,0078 & 1,0129 &,- 06814 &,- 06302 \\
\hline & Tinggal & Rural & 44938 & 1,1386 & 1,1339 & ,06267 & ,05796 \\
\hline
\end{tabular}

Hasilnya, ibu yang mengetahui siklus ovulasi dan/atau tinggal di kota memiliki rata-rata jumlah anak yang lebih sedikit dibanding dengan ibu yang tidak mengetahui siklus ovulasi dan/atau tinggal di desa. Sedangkan nilai grandmean berada pada tabel cell-means, dan diperoleh nilai sebesar 1,0759. Pada awal pengolahan, data telah ditransformasi dengan logaritma natural, sehingga model MCA yang terbentuk adalah sebagai berikut :

$$
\ln T C E B=\hat{\bar{Y}}+\widehat{P S O}_{\imath}+\widehat{W T T}_{j}
$$


TCEB : Total Children Ever Born (Jumlah Anak yang Dolahirkan Hidup)

$\mathrm{PSO}_{\mathrm{i}}$ : Pengetahuan Siklus Ovulasi kategori ke-i

WTT $_{\mathrm{j}}$ : Wilayah Tempat Tinggal kategori ke-j

Diperoleh rata-rata jumlah anak yang dilahirkan oleh ibu dari masing-masing kategori adalah sebagai berikut :

Tabel 6 Perhitungan Model MCA

\begin{tabular}{|c|c|c|}
\hline \multirow{2}{*}{$\begin{array}{c}\text { Pengetahuan ibu tentang } \\
\text { siklus ovulasi }\end{array}$} & \multicolumn{2}{|c|}{ Wilayah tempat tinggal } \\
\hline & Pedesaan & Perkotaan \\
\hline (1) & (2) & (3) \\
\hline Tahu & 3,039 & 2,69 \\
\hline Tidak Tahu & 3,36 & 2,978 \\
\hline
\end{tabular}

Seorang ibu yang mengetahui siklus ovulasi dan bertempat tinggal di pedesaan dan pekotaan masingmasing memiliki rata-rata jumlah anak yang dilahirkan sebanyak 3-4 dan 2-3 anak. Hal yang sama juga terjadi pada ibu yang tidak mengetahui siklus ovulasi baik di wilayah pedesaan dan perkotaan.

\section{Besar Pengaruh Variabel Bebas}

Besar pengaruh setiap variabel bebas terhadap variabel tak bebas dapat dilihat dari nilai Beta $(\beta)$. Sedangkan $\mathrm{R}^{2}$ menunjukkan seberapa besar model dapat menjelaskan variabel tak bebas. Berikut merupakan hasil beta dan $\mathrm{R}^{2}$.

Tabel 7 Output Besar Pengaruh Variabel Bebas

\begin{tabular}{|c|c|c|c|c|c|}
\hline & & \multicolumn{3}{|c|}{ Beta } & \multirow{2}{*}{$\begin{array}{c}\mathrm{R} \\
\text { Squared }\end{array}$} \\
\hline & & Eta & $\begin{array}{r}\text { Adjusted for } \\
\text { Factors }\end{array}$ & $\mathrm{R}$ & \\
\hline & & (1) & (2) & (3) & (4) \\
\hline \multirow[t]{5}{*}{ TCEB } & Pengetahuan &, 087 &, 073 & 0,141 & 0,02 \\
\hline & Siklus Ovulasi & & & & \\
\hline & Wilayah &, 121 &, 111 & & \\
\hline & Tempat & & & & \\
\hline & Tinggal & & & & \\
\hline
\end{tabular}

Variabel yang paling berpengaruh terhadap jumlah anak yang dilahirkan adalah wilayah tempat tinggal dengan nilai beta 0.111 , lalu diikuti oleh variabel pengetahuan ibu tentang siklus ovulasi dengan nilai beta 0.073 . Sedangkan kedua variabel tersebut secara bersama-sama dapat menjelaskan variasi banyak anak yang dilahirkan wanita di Indonesia berdasarkan data SDKI 2017 sebesar $2 \%$.

\section{KESIMPULAN}

Berdasarkan hasil analisis, dapat diketahui bahwa variabel pengetahuan ibu terhadap siklus ovulasi dan wilayah tempat tinggal secara simultan maupun parsial berpengaruh signifikan terhadap jumlah anak yang dilahirkan. Secara rata-rata seorang ibu yang mengetahui siklus ovulasinya dan/atau bertempat tinggal di kota memiliki rata-rata jumlah anak yang lebih sedikit dibanding dengan ibu yang tidak mengetahui siklus ovulasinya dan/atau bertempat tinggal di desa. Hal ini terjadi karena seorang ibu yang mengetahui siklus ovulasinya, lebih dapat mengontrol kejadian kehamilan dibanding dengan ibu yang tidak mengetahui siklus ovulasinya.

Model MCA dapat menangani data dengan variabel bebas berskala paling rendah yaitu nominal. Selain itu MCA juga dapat memperlihatkan efek terhadap variabel tak bebas baik sebelum maupun sesudah dikontrol oleh variabel bebas lainnya (adjusted dan unadjusted). 
Hasil penelitian ini dapat memberikan rekomendasi kepada pemerintah dalam hal pemerataan infrastruktur kesehatan di wilayah perdesaan maupun perkotaan sehingga dapat menekan jumlah anak yang dilahirkan. Selain itu, penelitian ini dapat memberikan edukasi terhadap wanita pentingnya mengetahui siklus ovulasi.

Namun, penelitian ini masih memiliki keterbatasan yaitu metode yang digunakan masih mengabaikan adanya faktor interaksi antar variabel, sehingga disarankan dalam penelitian selanjutnya menggunakan metode lain yang dapat mencakup faktor interaksi seperti misalnya metode RLB.

\section{DAFTAR PUSTAKA}

Atalya. Yusrina. (2020). Menentukan Masa Subur dengan Metode Kesadaran Fertilitas. Ibupedia.com.

Badan Pusat Statistik. (2020). Anak Lahir Hidup (ALH). Jakarta : Sirusa Badan Pusat Statistik Republik Indonesia.

Badan Pusat Statistik. (2016). Profil Penduduk Indonesia Hasil SUPAS 2015.

Badan Pusat Statistik. (2018). Survei Demografi dan Kesehatan Indonesia 2017.

Bhowmik and Das. (2017). On Exploring and Ranking Risk Factors of Child Malnutrition In Bangladesh Using Multiple Classification Analysis. Bangladesh : Shahjalal University of Science \& Technology.

Firdaus, Alvin. Shantika Martha, Nurfitri Imro'ah. (2019). Penentuan Garis Kemiskinan Provinsi Menggunakan Metode Multiple Classification Analysis. Pontianak : Universitas Tanjungpura.

Guevaraa, Cristian Angelo. Alan Thomas. (2007). Multiple Classification Analysis In Trip Production Models. Santiago, Chile : Universidad de Los Andes, San Carlos de Apoquindo.

Halodoc. (2020). Inilah Pentingnya Mengetahui Ovulasi dan Masa Subur. Jakarta : Redaksi Halodoc.

Hermanto, Rudi. T. Zulham, Chenny Seftarita. (2016). Analisis Determinan Pendapatan Pekerja Miskin di Provinsi Aceh Tahun 2015. Banda Aceh : Syiah Kuala University.

Jatmiko. (2019). Determinan Fertilitas Di Indonesia Hasil SDKI 2017. Cirebon : Universitas Swadaya Gunung Jati.

Lolle, Henrik Lauridsen. (2020). Multiple Classification Analysis (MCA). An, Unfortunately, Nearly Forgotten Method For Doing Linear Regression With Catagorical Variables. Denmark : Aalborg University Copenhagen Business School and Statistics.

Nasrullah. (2013). Pengaruh Migrasi dan Faktor Sosial Ekonomi Demografi Terhadap Fertilitas di DKI Jakarta. Widyariset, Vol. 16 No.1, April 2013: 101-110

Sugiarto. (2018). Multiple Classification Analysis (MCA) sebagai Metode Alternatif Analisis Data Untuk Variabel Bebas yang Kategori. Semarang : Universitas Muhammadiyah Semarang (Unimus).

Susel, Aleksander. (2011). Multiple Classification Analysis. Theory and Application To Demography. Polandia : Acta Universitatis Lodziensis, Folia Oeconomica.

Yuniarti, Sri. (2013). Analisis Faktor yang Berhubungan dengan Fertilitas. Bandung : Universitas Padjadjaran.

WHO. (2004). Maternal Mortality Ratio (Per 100.000 Live Birth). 